ZOOLOGIA 31 (4): 323-328, August, 2014

http://dx.doi.org/10.1590/S1984-46702014000400003

\title{
Genotoxic effect of Phenanthrene on Chironomus sancticaroli (Diptera: Chironomidae)
}

\author{
Gisele dos Santos Morais ${ }^{1}$, Emanuele Cristina Pesenti², \\ Marta Margarete Cestari² \& Mário Antônio Navarro-Silva ${ }^{1,3}$
}

\author{
${ }^{1}$ Laboratório de Entomologia Médica e Veterinária, Departamento de Zoologia, Universidade Federal do Paraná. Caixa Postal \\ 19020, 81531-980 Curitiba, Paraná, Brazil. \\ ${ }^{2}$ Laboratório de Citogenética Animal e Mutagênese Ambiental, Departamento de Genética, Universidade Federal do Paraná. \\ Caixa Postal 19071, 81531-980 Curitiba, Paraná, Brazil. \\ ${ }^{3}$ Corresponding Autor: E-mail: mnavarro@ufpr.br
}

\begin{abstract}
Phenanthrene, a Polycyclic Aromatic Hydrocarbon, remains adsorbed to sedimentary particles in aquatic environments. It affects mainly benthic organisms, and is considered potentially genotoxic. In ecotoxicology, species of Chironomus Meigen, 1803 are widely known as bioindicators of the effects of chemicals on aquatic organisms. This study investigates the effects of phenanthrene on the size of the head capsule of Chironomus sancticaroli Strixino \& Strixino, 1981 larvae after chronic (eight days) exposure, and DNA damage after acute (96 hours) and chronic exposure (eight days), under laboratory conditions. DNA damage, evaluated using the alkaline comet assay, detected effects for both exposure periods, indicating that phenanthrene is toxic for C. sancticaroli. For the acute exposure, we analyzed five concentrations of phenanthrene, between $0.16 \mathrm{mg} . \mathrm{I}^{-1}$ and $1.60 \mathrm{mg} . \mathrm{I}^{-1}$, detecting significant differences (KruskallWallis test with $p \leqslant 0.05)$ in the degree of DNA damage in all groups. These effects were not dose-dependent. For the chronic exposure, two concentrations $\left(0.16 \mathrm{mg}^{-1} \mathrm{I}^{-1}, 0.83 \mathrm{mg.l^{-1 }}\right)$ were analyzed, and DNA damage was observed in both. Again, the effects were not dose-dependent. This indicates that phenanthrene is genotoxic to larvae of $C$. sancticaroli even at low concentrations. The size of the head capsule was evaluated after chronic exposure to concentrations of 0.16 mg. $\left.\right|^{-1}$ and $0.83 \mathrm{mg}^{\mathrm{I}^{-1}}$. Significant differences (ANOVA test with $\mathrm{p} \leqslant 0.05$ ) were detected in the two concentrations, and a reduction in the size of the larval head capsule was observed. This suggests that phenanthrene causes delay in larval development. These results indicate that phenanthrene affects the development of and causes DNA damage in C. sancticaroli larvae. Therefore, we suggest that C. sancticaroli can be used as a biological indicator for environmental contamination with phenanthrene.
\end{abstract}

KEY WORDS. Bioassay; bioindicador; development; DNA damage; PHAs.

Polycyclic Aromatic Hydrocarbons (PAHs) are chemicals contaminants. They are considered a priority in the study of environmental contamination (Meire et al. 2007) because they are extensively distributed in aquatic and terrestrial environments and are toxic. Some PAHs are potential mutagens and carcinogens (WHO 1998).

Environmental contamination with PAHs results from anthropogenic activities such as fossil fuel burning, accidental spillage of oil and inadequate disposal of industrial effluents (JACQUes et al. 2007, Meire et al. 2007). In the aquatic environment, these compounds remain adsorbed to sediment particles and to suspended organic matter (NетTo et al. 2000). Therefore, benthic invertebrates are directly exposed to PAHs, which are toxic in after short and prolonged exposure (PAUMEN et al. 2008).

Phenanthrene is one of the 16 PAHs that are considered relevant for environmental monitoring by the United States
Environmental Agency. It is potentially genotoxic, mutagenic and neurotoxic (USEPA 1986, MARTYNIUK et al. 2009). Even though the effects of Phenanthrene at the cellular level are still poorly understood, it inhibits protein synthesis, thereby suppressing the immune system of organisms such as earthworms, insects and mollusks (Brown et al. 2010, Hannam et al. 2010, Marinkovic et al. 2011).

Among benthic invertebrates, Chironomus larvae are used as bioindicators of the impact caused by environmental contaminants (Michailova et al. 2010). Toxicity can be detected at the various organization levels of these insects, for instance molecular and population level. Toxicity at the molecular level can be evaluated by observing chromosomal polytene mutations and DNA strand breaks. At the level of populations, on the other hand, toxicity is expressed as changes in size, fecundity and weight of organisms (LeE \& CHOI 2006, PARK \& CHOI 2009, NAir et al. 2011).

2014 Sociedade Brasileira de Zoologia | www.sbzoologia.org.br | www.scielo.br/zool All content of the journal, except where identified, is licensed under a Creative Commons attribution-type BY-NC. 
Responses that occur at the molecular level determine the early effects on populations (Freire et al. 2008). The comet assay is an important tool for assessing genotoxicity, and has been employed in the detection and quantification of DNA damage such as breaks, alkali-labile sites and crosslinks (Cotelle \& Férard 1999, Platt et al. 2008). The alkaline comet assay has been used to detect toxicity in Chironomidae after exposure to nonylphenol, bisphenol A and silver nitrate (LeE \& Сно 2006, Park \& Choi 2009, Nair et al. 2011, Al-Shami et al. 2013).

Even though phenanthrene is found in aquatic environments and chironomids are important bioindicators, the effects of phenanthrene on different levels of the biological organization of these insects are poorly understood. Such information may be important for environmental monitoring and for assessing the environmental risks of having phenanthrene in aquatic ecosystems.

The objective of the present study was to evaluate the genotoxic effect of phenanthrene on the DNA of Chironomus sancticaroli Strixino \& Strixino, 1981 after acute (96 hours) and chronic (eight days) exposure and on the size of the head capsule, after chronic exposure (eight days), under laboratory conditions.

\section{MATERIAL AND METHODS}

Chironomus sancticaroli individuals were obtained from a colony and were maintained following the protocol of MAIER $\&$ Kosalwat (1990): temperature $25 \pm 2^{\circ} \mathrm{C}$, photoperiod of 12 hours $/ 2$ hours, $80 \%$ humidity \pm 10 , aeration constant and nutrition with Dog Chow $^{\circledR}$ ration. Voucher specimens of this colony are deposited in Coleção Entomológica Padre Jesus Santiago Moure of the Departamento de Zoologia, Universidade Federal do Paraná (DZUP) with accession numbers from 249269 to 249276 .

The quality of the colony was evaluated with the reference compound potassium chloride $(\mathrm{KCl})$. The test resulted in a range of 3.2 to 5.2 (Program Trimmed Spearman - Karber), an average $\mathrm{LC}_{50}$ of 4.21 , and a coefficient variation equal to $11.8 \%$. These results, within the acceptable range value $\leqslant 30 \%$, indicate that the colony presented ideal conditions for giving adequate responses to exposure to xenobiotics (USEPA 2000).

Toxicity tests were conducted following the Guidelines for the Testing of Chemicals 219 (OECD 2004), with the following modifications: instead of first instar larvae, second instar larvae were used in the chronic exposure experiment; photoperiod was 16:16 hours instead of 12:12 hours light: dark regimen. The experiments were conducted in $300 \mathrm{ml}$ glass beakers, with $95 \mathrm{~g}$ of artificial substrate (75\% fine sand, $20 \%$ clay white, $5 \%$ topsoil and $0.01 \%$ calcium carbonate) and $120 \mathrm{ml}$ of reconstituted water ( $8 \mathrm{ml}$ solution I: calcium sulfate $\left(\mathrm{CaSo}_{4}\right)$; $1000 \mathrm{ml}$ distilled water and $4 \mathrm{ml}$ solution II: potassium chloride $(\mathrm{KCl})$; sodium hydrogen carbonate $\left(\mathrm{NaHCo}_{3}\right)_{;} 1.000 \mathrm{ml}$ distilled water adjusted to hardness level of 16 . Specimens were kept under static conditions at $25 \pm 2^{\circ} \mathrm{C}$ and $12: 12$ hours light:dark regimen (STRIXINo \& STRIXINo 1985). Before use, the sand was washed with tap water and sterilized in an oven for five hours at $100^{\circ} \mathrm{C}$.

Water quality was assessed through the following physicochemical parameters: temperature $21.5^{\circ} \mathrm{C}, \mathrm{pH} 7.5 \pm 5$, conductivity $96.8 \pm 10 \mu \mathrm{S} . \mathrm{cm}$, salinity $46.2 \pm 2 \mu \mathrm{g} .1^{-1}\left(\right.$ ExStik II $\left.{ }^{\circledast}\right)$ and hardness by titration with EDTA (dimethylethylene acetic acid) $19.5 \pm 4 \mathrm{mg} \mathrm{CaCo}_{3}$. The glassware used in the experiments was cleaned in 5\% nitric acid solution for 24 hours. Phenanthrene 97.0\% (Fkuka - Sigma Aldrich) was diluted in acetone and ethanol, with end concentration of phenanthrene at $4.000 \mathrm{mg} \cdot \mathrm{l}^{-1}$.

After the acute toxicity (96 hours) and chronic toxicity (eight days) essays we evaluated DNA damage on C. sancticaroli larvae exposed to phenanthrene. The objective of the acute exposure bioassay was to determine the lethal concentrations of the compound, and that of the chronic exposure was to evaluate the size of the larval head capsule.

For the acute toxicity bioassays, egg masses were removed from the colony and kept in trays with four liters of reconstituted water for seven days. The food consisted of $0.32 \mathrm{~g}$ fish feed TetraMin ${ }^{\circledR}$ triturated every two days. Late third instar/early fourth instar larvae were exposed to phenanthrene. Each replicate contained 10 larvae. There were two control groups: one treated with a solvent (ethanol) and the other treated with reconstituted water only. In the end of the bioassay, all larvae (live and dead) were counted. Dead larvae had stretched bodies, no color and did not move.

The lethal concentrations (LC) were determined by the mortality data under the following concentrations of phenanthrene: $1.4 \mathrm{mg} . \mathrm{l}^{-1}, 1.5 \mathrm{mg} . \mathrm{l}^{-1}, 1.6 \mathrm{mg} . \mathrm{l}^{-1}, 1.7 \mathrm{mg} . \mathrm{l}^{-1}$ and $1.8 \mathrm{mg} . \mathrm{l}^{-}$ ${ }^{1}$. From these concentrations we were able to estipulate the concentrations used in acute exposure $0.16 \mathrm{mg}^{-1} \mathrm{l}^{-1}$ (NOEC), 0.83 mg..$^{-1} 1.06$ mg. $.^{-1}, 1.34$ mg. $.^{-1}, 1.6$ mg..$^{-1}$ (Tab. I).

Table I. Lethal concentrations (LC) of phenanthrene for the acute exposure of Chironomus sancticaroli, expressed in $\mathrm{mg}^{-\mathrm{l}^{-1}}$, with confidence interval $(\mathrm{Cl})$.

\begin{tabular}{ccc}
\hline Lethal concentrations & $\mathrm{Mg.l}^{-1}(\mathrm{ppm})$ & $\mathrm{Cl}$ \\
\hline LC 2 & 0.83 & $0.421-1.033$ \\
LC 10 & 1.06 & $0.694-1.201$ \\
LC 30 & 1.34 & $1.128-1.419$ \\
LC 50 & 1.60 & $1.510-1.655$ \\
LC 90 & 2.34 & $2.022-3.683$ \\
LC 99 & 3.20 & $2.503-7.244$ \\
\hline
\end{tabular}

The concentrations used in the chronic toxicity assays were defined based on mortality data obtained in the acute exposure experiment. Second instar larvae were more vulnerable than late third instar early fourth instar. High mortality 
rates were observed in the lethal concentrations of $\mathrm{LC}_{5}(0.94$ mg..$\left.^{-1}\right), \mathrm{LC}_{8}\left(1.01 \mathrm{mg} . \mathrm{l}^{-1}\right), \mathrm{LC}_{10}\left(1.05 \mathrm{mg} . \mathrm{l}^{-1}\right) \mathrm{LC}_{20}\left(1.21 \mathrm{mg} . \mathrm{l}^{-1}\right)$ with $96 \%, 99 \%, 100 \%$ and $100 \%$, respectively. In chronic toxicity tests, second instar larvae were exposed to NOEC (No Observed Effect Concentrations calculated by $\left.\mathrm{LC}_{50} / 10\right) 0.16 \mathrm{mg} \cdot \mathrm{l}^{-1}, 0.83$ $\mathrm{mg} \cdot \mathrm{l}^{-1}\left(\mathrm{LC}_{2}\right)$. As in the acute toxicity test, there were two control groups, one treated with reconstituted water, and the other with a solvent (ethanol) for eight days. Twenty larvae were added to each replicate. The containers remained closed under constant aeration (OECD 2004). Every two days the water was changed by removing approximately $70 \%$ of the total volume. Together with the water we added $4.8 \mathrm{mg} / \mathrm{ml}$ fish feed, TetraMin $^{\circledast}$ and phenanthrene solution for each specific concentration, due to the two-day half-life of phenanthrene in sediment (NetTo et al. 2000).

After eight days under chronic exposure, larvae were stored in $80 \%$ alcohol. Specimens were cleared in $10 \%$ potassium hydroxide $(\mathrm{KOH})$ solution for 24 hours. They were then mounted on slides (Acrilex) with the ventral region of the head capsule facing up. The length of the head capsule was measured as indicated by STrixino \& STRIXINo (1982) using the program ZEN 2011 "blue edition", from photos taken under a dissecting scope and magnified 150x (Zeiss SteREO Discovery V20 coupled with AxioCam camera ERc5s).

DNA damage was determined by alkaline comet assay for the following concentrations of the acute exposure experiment: $0.16,0.83,1.06,1.34$, and $1.6 \mathrm{mg}^{-1}{ }^{-1}$; and the following concentrations for the chronic exposure: 0.16 and $0.83 \mathrm{mg} . \mathrm{l}^{-1}$. We followed the method of LEE \& CHOI (2006), with the following modifications: $1 \mathrm{ml}$ PBS solution for $250 \mu$ of the bovine serum was followed by a centrifugation phase. Ten larvae taken from the bioassay were macerated in $2 \mathrm{ml}$ eppendorf tubes containing 250 il bovine serum and centrifuged at $1.000 \mathrm{rpm}$ for five minutes. The supernatant was discarded and the cells resuspended by vortexing. Then 60 il of the suspension were mixed with 120 il low meeting point agarose (LMP) 0.5\% (0.1 g, $20 \mathrm{ml}$ dimethylethylene acetic acid and phosphate buffered saline (PBS)) and immediately placed on a slide coated with normal agarose $1.5 \%(1.5 \mathrm{~g}, 100 \mathrm{ml}$ dimethylethylene acetic acid and phosphate buffered saline (PBS)), covered with cover slip and kept refrigerated for 10 to 20 minutes. Subsequently, the cover slips were removed and slides were placed in lysis solution $(10 \mathrm{mM}$ Tris; $100 \mathrm{mM}$ dimethylethylene acetic acid (EDTA), $2.5 \mathrm{M}$ chloride sodium ( $\mathrm{NaCl}$ ); dimethylsulffoxide (DMSO) 10\%) for 24 hours. After being removed, the slides were kept in alkaline solution $(300 \mathrm{mM}$ sodium hidroxide $(\mathrm{NaOH}) ; 1 \mathrm{mM}$ dimethylethylene acetic acid (EDTA)) for 30 minutes to denature the DNA. Slides were then subjected to electrophoresis (25 volts and $300 \mathrm{~mA}$ ) for 25 minutes. When the migration ended, slides were neutralized with $0.4 \mathrm{M}$ Tris (pH 7.5) and subsequently fixed with absolute ethanol for five minutes and colored with 15ìl of Ethidium Bromide (20 ìg/ $\mathrm{ml})$. The slides were analyzed under epifluorescence micros- copy (LEICA) at 400x magnification. The degree of DNA damage was evaluated visually and classified into four categories: 0 (no damage), 1 (little damage), 2 (average damage), 3 (considerable damage) and 4 (maximum damage). A total of 50 cells corresponding to each replicate were evaluated (КовауASH et al. 1995). For each slide, the degree of damage was calculated by summing up the number of cells with each kind of damage and multiplying the resulting number by the number corresponding to the category of damage. The score ranged from 0 (no damage: $50 \times 0$ ) to 200 (maximum damage: $50 \times 4$ ). All bioessays (in the control and treatment) were analyzed, 15 replicates, totaling 750 cells.

The lethal concentrations were obtained in GW-Basic Probit version 5.0. To evaluate genotoxicity the statistical analyzes were performed using the Kruskal-Wallis $(p \leqslant 0,05)$ through BioEstat version 5.0 and measured head capsule data were analyzed by ANOVA $(p \leqslant 0,05)$ with Tukey's $(p \leqslant 0,05)$ post test using the program PAST version 1.95. The graph was produced using GraphPad Prism version 5.0.

\section{RESULTS}

In the alkaline comet assay, no significant differences among the control groups were detected $(p=0.700)$ by the Kruskall-Wallis test, with $\mathrm{p} \leqslant 0.05(5 \%)$ in acute exposure $(96$ hours). All groups showed significant differences with respect to the control group $(\mathrm{p}<0.001)$. However, when we compared among the different concentrations, significant differences were observed only between $0.16 \mathrm{mg} . \mathrm{l}^{-1}$ and $1.06 \mathrm{mg} . \mathrm{l}^{-1,}$ with $\mathrm{p}=0.042$ (Fig. 1). A concentration-dependent response was not detected.

In the chronic exposure (eight days), no significant differences were found between the two control groups $(\mathrm{p}=0.960)$. In the analyses evaluating concentrations $\left(0.16\right.$ and $0.83 \mathrm{mg} . \mathrm{l}^{-}$ 1) there were significant differences between experiment and water control, with $\mathrm{p}<0.0001$ for both. However, significant differences were not detected between treatments groups, with $\mathrm{p}=0.421$ (Fig. 2). A concentration-dependent response was not detected.

There were no significant differences in the size of the head capsule of individuals subjected to chronic exposure to phenanthrene between the control groups $(\mathrm{p}=0.42$ by ANOVA $\mathrm{p} \leqslant 0.05(5 \%)$ ), indicating that the solvent does not affect the development of $C$. sancticaroli. In the two concentrations tested, significant differences were found, with $\mathrm{p}=4.281$ at $0.16 \mathrm{mg} . \mathrm{l}^{-}$ ${ }^{1}$ and $\mathrm{p}=1.913$ at $0.83 \mathrm{mg} . \mathrm{l}^{-1}$ (Fig. 3). However, between the two concentrations of phenanthrene in the chronic bioassay, no significant difference was detected, with $\mathrm{p}=0.369$, and the response was not concentration-dependent. The Tukey's test at $p \leqslant 0.05(5 \%)$ performed retrospectively confirmed this. There was a significant difference for both concentrations with respect to the control $\left(\mathrm{p}=7.72\right.$ at $0.16 \mathrm{mg} . \mathrm{l}^{-1}$ and 7.72 at 0.83 mg..$^{-1)}$, but no significant differences between the concentrations $(\mathrm{p}=0.84)$. 

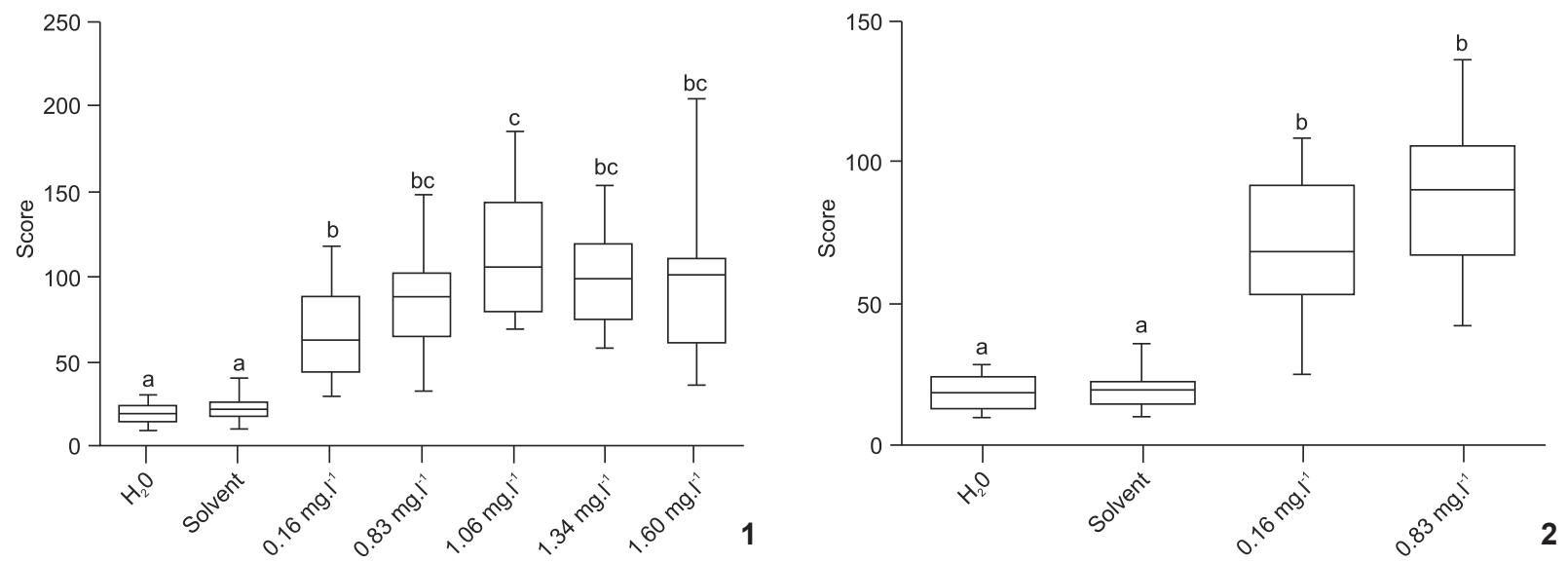

Figures 1-2. DNA damage in C. sancticaroli larvae demonstrating the medium and range minimum and maximum for control groups (water and solvent) and groups exposed to phenanthrene. Different letters indicate significant differences with $p \leqslant 0.05$ (KuskrallWallis test). (1) Acute exposure of 96 hours; (2) Chronic exposure of eight days. $N=15$.

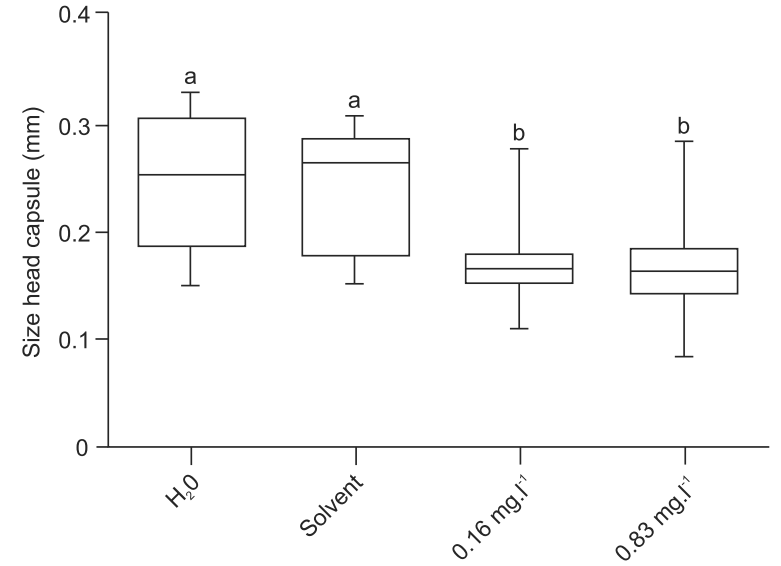

Figure 3. Size of the head capsule of C. sancticaroli larvae demonstrating the average, range minimum and maximum and standard deviation for control groups (water and solvent) and groups exposed to phenanthrene for eight days. Different letters indicate significant differences $p \leqslant 0.05$ (ANOVA one-way with aposteriori Tukey test).

\section{DISCUSSION}

We tested the toxic effects of phenathrene on the chironomid C. sancticaroli and found evidence of toxicity at both the molecular and population levels. Phenathrene was genotoxic to larvae after 96 hours and its effects continued up to eight days of exposure, causing delay in larval development.

Phenanthrene, in our data, had deleterious effects on $C$. sancticaroli at concentrations above $3.2 \mathrm{mg} . \mathrm{l}^{-1}$. After both acute and chronic exposure, second instar larvae were more vulnerable to the compound than late third instar and early fourth instar larvae. The high rate of larval mortality indicates that phenanthrene primarily affects survival. This effect had been previously described by MARINKOVIC et al. (2011) and PAUMEN et al. (2008) in a study using Chironomus riparus Meigen, 1804.

Genotoxicity is considered an important biomarker for environmental monitoring, but little information is known about the toxicity of phenanthrene on benthic organisms. However, DNA damage has been detected in Chironomidae, indicating the genotoxicity of nonylphenol, bisphenol A and silver nitrate (PARK \& CHOI 2009, NAIR et al. 2011).

The results of the alkaline comet assay for both acute and chronic toxicity tests suggest that phenanthrene is genotoxic to C. sancticaroli larvae. Significant DNA damage was observed after acute exposure, starting with the lower concentration of 0.16 mg. $1^{-1}$ by Kruskall-Wallis test $(p \leqslant 0.05)$. However, the occurrence of DNA breaks was not concentration-dependent. In chronic exposure tests we observed significant DNA damage at the two concentrations tested $\left(0.16\right.$ and $\left.0.83 \mathrm{mg} . \mathrm{l}^{-1}\right)$. However, DNA damage did not increase with increased concentrations. Our data indicate that phenanthrene reaches the interior of the cell, causing breaks in the genetic material.

Our results suggest that even low concentrations of phenanthrene cause DNA breaks in C. sancticaroli larvae after short exposure. This sensitivity may allow the identification of environmental contamination in its initial stages. The permanence of phenanthrene in the environment does not cause more serious DNA damage, even with a fivefold increased concentration, suggesting that $C$. sancticaroli larvae become resistant to the effects of the compound.

Phenanthrene is a Polycyclic Aromatic Hydrocarbon and its toxicity requires metabolic activation, which is associated with the process of detoxification. The compound can be metabolized rapidly, which reduces its toxic potential (NetTo et al. 2000, Marinkovic et al. 2012). According Marinkovic et al. (2011), exposure to phenanthrene activates the expression of proteins that repair DNA damage, and which may also act 
against the intensification of DNA breaking. DNA damage caused by phenanthrene is primarily sub lethal, and may cause long-term mutations, chromosomal aberrations and loss, altering the genetic structure of the population (Јна 2008).

Measurements of the head capsules showed significant reduction in the size of immatures under all concentrations of phenanthrene, averaging a $1.5 \mathrm{x}$ reduction with respect to the control, indicating delays in the development. According to MARINKovic et al. (2012), phenanthrene does not change the expression of the juvenile hormone (methyl transferase acid) in C. riparus. Thus, it is possible that phenanthrene exposure causes changes in other essential biological functions such as feeding, causing a reduction in the size of the head capsule.

Delays in larval development following food restrictions were observed by Liber et al. (1996) for Chironomus tentans Fabricius, 1805 and by Ristola et al. (1999) for C. riparus. In those studies, a reduction in the amount of food caused a reduction in larval size and a consequent delay in the emergence of adults. In the same manner, the reduced larval size could cause delays in the life cycle of $C$. sancticaroli. However further studies are needed to test this hypothesis.

Marinkovic et al. (2012) did not find any changes in the development of $C$. riparius after exposing larvae to high concentrations of phenanthrene. Likewise, PAUMEN et al. (2008) and MarinKovic et al. (2011) observed only a short delay in the emergence of $C$. riparus adults, indicating little to no delay in larval development. The results obtained suggest that it is possible to detect DNA damage and developmental delays in $C$. sancticaroli larvae after exposure to phenanthrene.

\section{LITERATURE CITED}

Al-Shami, S.A.; C.S. Rawi; S.A. Nor; A.H. Ahimad \& N.A. Ishadi. 2013. Genotoxicity in Chironomus kiiensis (Chironomidae: Diptera) after exposure to polluted sediments from rivers of north peninsular Malaysia: Inplication for ecotoxicological monitoring. River Research and Aplications 29 (9): 11951204. doi: 10.1002/rra.2594

Brown, S.A.; J.R. MCKELVIE \& A.J. SIMPSON. 2010. HNMR metabolomics of earthworn exposure to sub-lethal concentrations of phenanthrene in soil. Environmental Pollution 158 (6): 2117 2123. doi: 10.1016/j.envpol.2010.02.023

Cotelle, S. \& J.-F. Ferárd. 1999. Comet Assay in Genetic Ecotoxicology: A Review. Environmental and Molecular Mutagenesi 34 (4): 246-255.

Freire, M.M.; V.G. SAntos; I.S.F. Ginuinol \& A.R. Linde. 2008. Biomarcadores na Avaliação da Saúde Ambiental. In Oecologia Brasilienses 12 (3): 347-354.

Hannam, M.; S.D. Bamber; T.S. Galloway; A.J. Moody \& M.B. Jones. 2010. Effects of the mode $\mathrm{PAH}$ phenanthrene on imature function ond oxidative stress in the haemolymph of the temperature scallop Pectens maximus. Chemosphere 78 (7): 779-784. doi: 10.1016/j.chemosphere.2009.12.049
JaCQues, R.J.; F.M. BEnto \& Z.I. ANTONIOLLI. 2007. Biorremediação de solos contaminadas com hidrocarbonetos aromáticos policíclicos. Ciência Rural 37 (4): 1192-1201. doi: 10.1590/ S0103-84782007000400049

JнА, A.N. 2008. Ecotoxicological applications and significance of the comet assay. Mutagenesis 23 (3): 207-221. doi: 10.1093/mutage/gen014

Kobayashi, H.; C. Sugiyama; Y. Morikawa; M. Hayashi \& T.Sofuni. 1995. A comparison between manual microscopic analysis and computerized image analysis in the single cell gel electrophoresis. Mammalian Mutagenicity Study Group Communications 3: 103-115.

LeE, S.B. \& J. CHог. 2006. Multilevel evaluaion of Nonylphenol Toxicity in fourth-instar larval of Chironomus riparus (Diptera, Chironomidae). Environmental Toxicology and Chemistry 25 (11): 3006-3014. doi: 10.1897/05-601R1.1

Liber, K.; D.J. Call; T.D. Dawson; F.W. Whiteman \& T.M. Dillon. 1996. Effects of Chironomus tentans larval growth retartion on adult emergence and oviposition succes: implication for interpreting freshwater sediment bioassays. Hydrobiologia 323 (3): 155-167.

Maier, K.J. \& P. Kosalwat. 1990. Culture of Chironomus decorus (Diptera: Chironomidae) and efect of temperature on its life history. Environmetal Entomology 19 (6): 1681-1888.

Marinkovic, M.; R.A. Verwey; G.A. Numerador; M.J. Jonter \& M.H. KraAK. 2011. Life cycle responses of the midge Chironomus riparus to compounds with different mods of action. Environmental Science \& Techonology 45 (4): 1645-1651. doi: 10.1021/es102904y

Marinkovic, M.; W.C. Leeuw; W.A. Ensink; M. Jonk; T. M. Breit \& W. Admiral. 2012. Geni expression patterns and life cycle responses of toxicant exposed chiromids. Environmental Science \& Techhnology 46 (22): 1267-1286. doi: 10.1021/ es3033617

Martyniuk, C.J.; B.C. Sanchez; N.J. Szabo \& N.D. Denslow. 2009. Aquatic contaminants altergenes involved in neutransmitter synthesis and gonadotrophin release in largemouth bass. Aquatic Toxicology 95 (1): 1-9. doi: 10.1016/j.aquatox.2009.06.009

Meire, R.O.; A. Azeredo \& J.P.M. Torres. 2007. Aspectos ecotoxicológicos de hidrocarbonetos policíclicos aromáticos. Oecologia Brasilienses 11 (2): 188-201.

Michailova, P.; J. Ilkova \& K. White. 2010. Functional and structural rearrangements of salivary gland polytene chomossome o Chironomus riparus $\mathrm{Mg}$. (Diptera, Chironomidae) in response to freshly neutralized aluminium. Environmental Pollution 123 (2): 193-207. doi: 10.1016/S0269-7491(02)00405-0

NAIR, P.M.; S.Y. PARK \& S.W. LeE. 2011. Diferrential expression of ribosomal protein gene, gonadotrophin releasing hormone gene and Balbiani ring protein gene in silvar nanoparticles exposure Chironomus riparus. Aquatic Toxicology 101 (1): 31-37. doi: 10.1016/j.aquatox.2010.08.013

NetTo, A.D.P.; J.C. Moreira; A.E.X.O. Dias; G. Arbilla; L.F.V. Ferreira; A.S. Oliveira \& J. Barek. 2000. Avaliação da conta- 
minação humana por Hidrocarbonetos Policíclicos Aromáticos (HPAs) e seus derivados nitratos (NHPAS): Uma revisão metodológica. Química Nova 23 (6): 765-773. doi: 10.1590/S0100-40422000000600010

OECD. 2004. Test No. 219: Sediment-Water Chironomid Toxicity Using Spiked Water. OECD Guidelines for the Testing of Chemicals, Section 2, OECD Publishing. doi: 10.1787/9789264070288-en

PARK, S.Y. \& J. CHOI. 2009. Genotoxic effects of nonylphenol and bisfenol A exposure in aquatic biomonitoring species: Freshwater crustacean, Daphina magna and aquatic midge, Chironomus riparus. Bulletin of Environment Contaming Toxicologyc 83 (4): 463-468. doi: 10.1007/s00128-009-9745-1

Paumen, M.L.; M.H. Kraak \& C.A. Gestel. 2008. Life cycle responses of the midge Chironomus riparus to polycyclic aromatic compound exposure. Environmental Pollution 152 (1): 225-232. doi: 10.1016/j.envpol.2007.04.027

Platt, K.L.; S. Aderhold \& K. Kulpe. 2008. Unexpected DNA damage caused by policyclic aromatic hidrocarbons under standard laboratory conditions. Mutation Research/ Genetic Toxicology and Environmental Mutagenesis 650 (2): 96-103. doi: 10.1016/j.mrgentox.2007.09.011
Ristola, T.; J. Pellien; M. Ruokalainen; A. Kostano \& J.V.F. KuKKONEN. 1999. Effect of sediment type, feeding level, and larval density on growth and development of a midge (Chironomus riparus). Environmental Toxicology and Chemistry 18 (4): 756-764. doi: 10.1002/etc.5620180423

Strixino, T. \& G. Strixino. 1982. Ciclo de vida de Chironomus sancticaroli Strixino \& Strixino, (Diptera, Chironomidae). Revista Brasileira de Entomologia 26 (2): 183-189.

Strixino, G. \&. S.T. Strixino. 1985. A temperatura e o desenvolvimento larval de Chironomus sancticaroli (Diptera: Chironomidae). Revista Brasileira de Zoologia 3 (4): 177-180. doi: 10.1590/S0101-81751985000400003

USEPA. 1986. Quality criteria for water. Washington, D.C., United States Environmental Protection Agency, EPA 440/ 5-86-001, 477p.

USEPA. 2000. Methods for measuring the toxicity and bioaccumulation of sediment-associated contaminants with freshwater invertebrates. Washington, D.C., United States Environmental Protection Agency, EPA 600/R-99/064, 212p.

WHO. 1998. Polynuclear Aromatic hydrocarbons in Drinking Water. Guidelines for drink water quality. Geneva, World Health Organization,495-505p.

Submitted: 24.IV.2014; Accepted: 14.VII.2014.

Editorial responsibility: Carolina Arruda Freire

ZOOLOGIA 31 (4): 323-328, August, 2014 